general constitutional disease, the local secondary manifestation or deposit showing on the tonsil or fauces, the position varying, during the second day of the fever or not at all. Here let me draw attention to the extraordinary rapidity with which the diphtheritic membrane is capable of appearing and vanishing, a few hours only being . necessary for the completion of both acts. In this rests the secret of the so called cures by perchloride of mercury, iron, eucaJyptus oil, \&c. The post-diphtheritic throat redness, and enlargement of tonsils dotted with open follicular cavities, persist many weeks after apparent recovery, and might prove a source of contagion. The inference is forced upon the scientific mind that if the membrane fail to show itself, or become thrown off, no one can positively affirm that the person is or has been the subject of the specific complaint diphtheria. Confessedly, the differential diagnosis between this non-membranous form and the malignant sore-throat of bad drainage is impossible. What is the nature and frequency of the true, not accidental, rash which occasionally accompanies diphtheria? What are the distinguishing features between this exanthem and the efflorescence of scarlet fever? In the first the spots are apicular, reddish papules; to the touch they are very much like the shotty hillocks of goose-skin or lichen simplex. The individual points are isolated and acuminated trom beginning to end, have no surrounding red areola, and never fuse together to form extensive patches. Occurring in about 4 per cent. of instances, ind since they appear noost frequently on the third day of invasion, when the temperature is either normal or a little above, the rash becomes differentiated from that of scarlatina or the evanescent and accidental roseola, the forerunner, in chance instances, of diphtheria, small-pox, \&c. Generally limited to the hands, arms, and lege, it may cover the entire skin surface. The cuticle peels precisely as in scarlatina, although at nots so late a period. Thus it will be observed there is a close affinity between diphtheria and scarlatina; indeed, so much so that often there is extreme diagnostic difficulty at the outset as to which of them a given case will develop into. Here is produced a single example of this intimate relationship. In a house with faulty drsinage were under treatment at the same time a well-marked type of scarlatina and two of uncomplicated diphtheria. Can thev be, though modifications, one and the same disease? Is there such a thing as hybridism, or may the germ, implanted on varying soils, give origin to either malady? When the poisons commingle, danger to life is proportionately increased.

Barnsley.

\section{SUTURE OF THE ULNAR NERVE.}

\section{BY JOHN E. GARNER, M.D. ADERD.}

D. S- - a young man, aged eighteen years, while play ing with his brother in July, 1890, who had a large knife in his hand, accidentally turned round and cut bim in the arm, dividing the right ulnar nerve in the thickest part of the arm about two inches below the elbow. Sensation along the course of the ulnar nerve in the arm was quite lost, together with all feeling on the inside of the ring finger and both sides of the little finger. Considerable muscular atrophy of the arm and the ulnar side of the palm of the hand followed. The abductor minimi digiti and flexor brevis minimi digit seemed quite lost, and the hand was quite flat on the outside. Galvanism, rubbing, and other means, I believe, were tried with no avail. On April 1st, 189l, nine months after the accident, the ulnar nerve was sutured. It was with considerable difficulty that the ends of the nerve could be found; they seemed to have become continuous with the surrounding tissues, and the cicatricial tissue seemed to make the ends still more tedious to find. At last I fouad the nerve, and then traced it up to its divided end. Having got one end out, the other end was found by at once catting down on the course of the nerve from the ulnar and tracing it to the divided end. If in future $I$ have the same operation of suturing a divided nerve, I shall make the incislon sutficiently long to be well on each side of the cicatrix, so that the nerve can be dissected out to its divided seat from above and below respectively. The nerve having at length been found, I vivified the ends, and with two fine silk thread sutures brought the cut or divided ends into nice apposition. The wound was then thoroughly cleaned out, all points of hxomorrhage stopped stitched up, and dressed with dry dressings. I'he wound healed up uninterruptedly with no drawbacks.

On $\Lambda$ pril 2 nd (the day after the operation), at 9 A. $n$. , which. was three hours short of twenty-four hours from the time the nerve was sutured, the boy could feel distinctly when touched him on the fingers or on the arm. On the 3 cd (the second day after the operation) I asked the father of the boy to test his gensation. He did so with a feather by drawing it along the arm and on his fingers. Sensation was. quite evident; the boy could feel distinctly whenever he was touched. I examined him again on Oct. 26th, 1891. The arm was considerably increased in size, but the palm of the hand on the ulnar side was still very much atrophied. Tho sensation along the course of the ulnar nerve still remained good. He could feel a pen lightly drawn along the course of the nerve, or over the purts supplied by it.

The early return of the sensation after the suturing of the nerve seems very extraordinary; still, it is a fact and it certainly did occur.

Preston.

\section{de ethirror \\ OF}

\section{H O P I T A L PRACTICE, BRITISH AND FOREIGN.}

Nulla autem est alia pro certo noscendi via, nisi quamplurimas et mon borum et dissectionum historias, tum aliorum tum proprias collectai habere, et inter se comparare.-Morgagni De Sed. et Caus. Morb. I b. iv. Procemium.

\section{SEAMEN'S HOSPITAL.}

A CASE OF HEPATIC ABSCESS ; OPERATION ; RECOVERY. (Under the care of Dr. JoHN CURNow and Mr. Johnson SMITH.)

THE following case is an example of the successful treat ment of hepatic abscess by incision and drainage after resection of part of the chest wall. This part of the operation. resection of a piece of rib, is required very seldom in the evacuation of pus from a liver abscess. Another point in the operation is the attachment of the thickened capsule of the liver to the edges of the wound by means of sutures Dr. Chauvel, ${ }^{1}$ who has reported cases of this kind, says that the attachment of the capsule to the wound is " useless and possibly dangerous," but it was found to present advantages nere. For the report of this case we are indebted to Dr. M. H. Spencer, house physician.

Michael M-, aged thirty, was admitted into the Sea. men's Hospital on Aug. 15th, 1891, suffering from dysentery. The dysentery commenced six weeks before, when the patient was in Calcutta. The stools contained a good deal of blood and slime, and were at first very frequent, but hact become less so lately.

On admission there was marked tenderness over the cæcum, but none elsewhere; the tongue was dry and rather furred; the temperature $101 \cdot 2^{\circ}$. During the next ten days the patient's condition improved somewhat, but the dysen. tery, although checked, was not completely stopped. On August 24th pain was first complained of over the liver; nc enlargement of the organ was detected. On the 26th the dysentery had stopped, but there was still pain over the hepatic region, and a tender spot was detected below the costal margin on the right side. The temperature was generally above $100^{\circ}$ at night, falling to normal in the morning. On Sept. 5 th the pain was still severe, and prevented sleep : the temperature still kept above normal. Mr Smith introduced the needle of an exploring syringe between the seventt: and eighth ribs on the right side, near their junction with the cartilage, and at once drew off a syringeful of pus. On the next day ether was administered and the abseess was opened, a portion of the seventh rib and its cartilage being removed and a large drain inserted. The abscess cavity was the size of a large apple; toere were firm adhesions between the liver and the parietes in front of and below the opening, but, above, the finger could be passed freely over the upper surface of the right lobe. After incision of the liver the edges of the thickened 